The Status of Nuclear Power Plants

in the People's Republic of China

Jason Puckett*

* Summer undergraduale student. Swing Hall, Rm. 72, Miami University, Oxford, $\mathrm{OH} 45056$. 


\section{EXECUTIVE SUMMARY}

China's proven coal reserves are in the north and northwest of the country, but much of its industry is along the coast in the south. About $40 \%$ of the rail and $50 \%$ of the main waterways are used to transport coal. The energy transport system cannot keep up with demand, limiting the hours that industry can operate.

In addition to lessening the strain on the power generation network as well as the transportation system, the nuclear option brings with it the attraction of the prestige and status of a world power to offset high capital costs. China has two nuclear power plants under construction at Qinshan and Daya Bay.

Qinshan is a two-loop pressurized water reactor with a capacity of $300 \mathrm{MWe}$ and a thermal output of $966 \mathrm{MW}$. When it is completed it is expected to supply 2 million MWh per year to the East China power grid. Qinshan is an indigenously built power plant. Initial construction at the plant was defective, forcing corrective measures. A scheduled opening for mid 1990 was postponed because of safety considerations. Initial power production is now scheduled for August 1991.

Daya Bay, which is near Hong Kong, will have two pressurized water reactors with an electric capacity of $900 \mathrm{MW}$ each. The thermal output of each plant is $2905 \mathrm{MW}$. Electricite de France is project consultant. Framatome of France is supplying the nuclear portion, General Electric of Great Britain the generators, and the civil works involve Campenon-Bernard of France, Maeda of Japan, Hua Xing of Chira, and the Second Branch of the China State Construction Corporation. The planned completion dates are October 1992 for Unit 1 and July 1993 for Unit 2, but 1994 has also been estimated for completion of the plants. Early construction at Daya Bay has also been defective, forcing corrective measures and delays.

China is expected to reprocess its spent fuel for reasons of economy and safer waste disposal. However, China is in the early phases of developing waste processing. 


\section{CONTENTS}

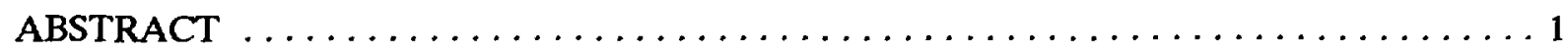

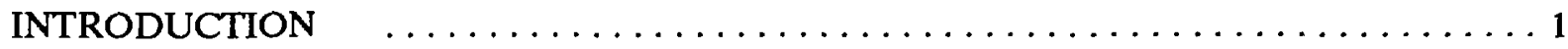

THE NEED FOR NUCLEAR POWER $\ldots \ldots \ldots \ldots \ldots \ldots \ldots \ldots \ldots \ldots \ldots \ldots$

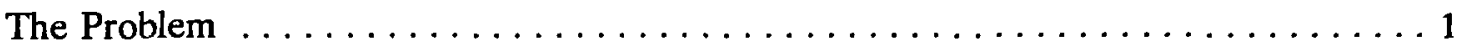

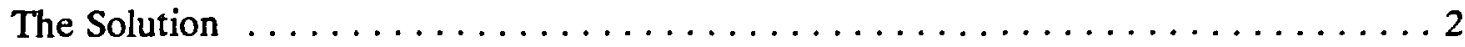

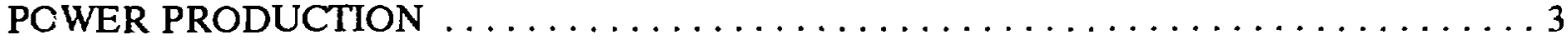

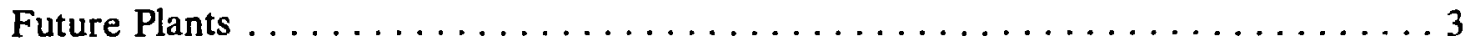

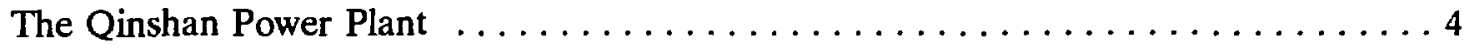

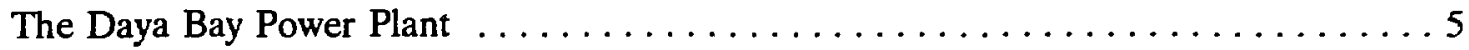

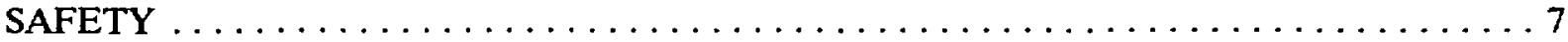

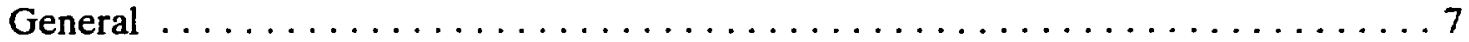

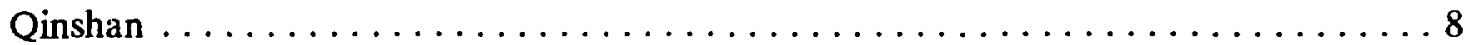

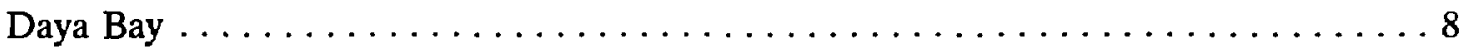

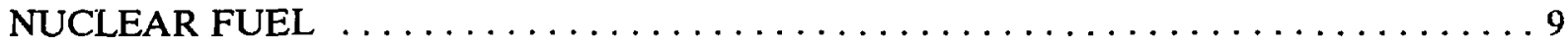

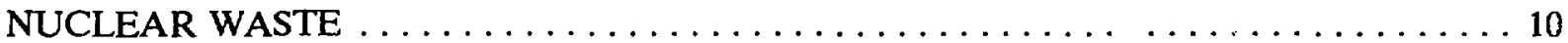

Disposal ................................. 10

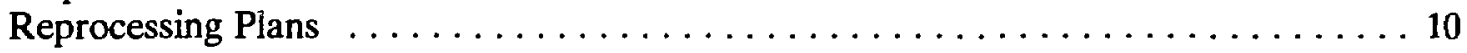

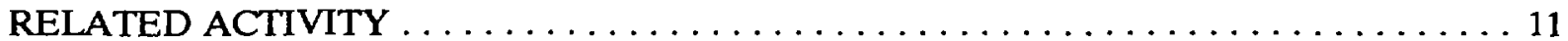

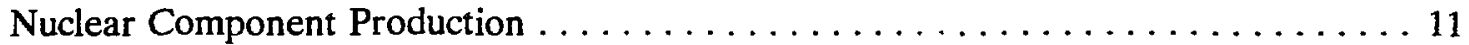

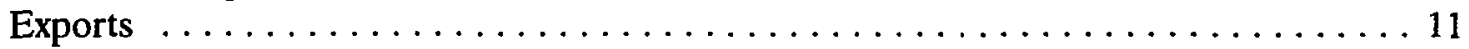

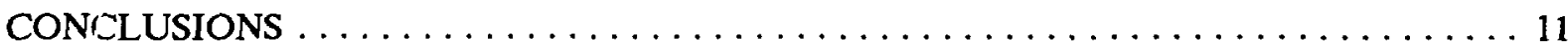

ACKNOWLEDGMENT $\ldots \ldots \ldots \ldots \ldots \ldots \ldots \ldots \ldots \ldots \ldots \ldots \ldots \ldots \ldots \ldots \ldots \ldots$

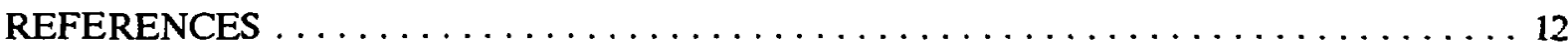

APPENDIX: CHINESE NUCLEAR RESEARCH REACTORS $\ldots \ldots \ldots \ldots \ldots \ldots \ldots$ 


\title{
THE STATUS OF NUCLEAR POWER PLANTS IN THE PEOPLE'S REPUBLIC OF CHINA
}

\author{
by
}

Jason Puckett

\begin{abstract}
China's main energy source is coal, but transportation and environmental problems make that fuel less than desirable. Therefore, the Chinese, as part of an effort toward alternative energy sources, are developing nuclear power plants. In addition to providing a cleaner power source, development of nuclear energy would improve the Chinese economic condition and give the nation greater world status. China's first plants, at Qinshan and Daya Bay, are still incomplete.

However, China is working toward completion of those reactors and planning the training and operating procedures needed to operate them. At the same time, it is improving its nuclear fuel exports. As they develop the capability for generating nuclear power, the Chinese seem to be aware of the accompanying quality and safety considerations, which they have declared to be first priorities.
\end{abstract}

\section{INTRODUCTION}

Many developing nations are struggling to develof themselves. China is a prime example, one of whose many struggles is the effort to provide energy for its citizens and factories. Much of the information in this report comes from Chinese sources, reflecting the optimism and attitude of the Chinese government.

\section{THE NEED FOR NUCLEAR POWER}

\section{The Problem}

China has an energy crisis caused, not by a lack of resources, but by an inability to use them efficiently. Its main energy resource is coal; China has a proven coal reserve of 840 billion tons. Most coal reserves are located in the northern and northwestern portion of the country, away from the industrial section along the coast in the south, thus placing a tremendous strain on China's transportation system. ${ }^{1}$ Almost $40 \%$ of the rail capacity and $50 \%$ of the main waterways are used to transport coal, and still the demand cannot be met. ${ }^{2}$ As a result, China 
cannot produce enough energy for its people. In 1988, industrial output surged by $17.2 \%$ while energy resources grew less than $4 \%$. A ministry report from 1989 showed that China lacks 30 million tons of coal and 50 billion kilowatts of electricity each year. ${ }^{3}$ In Beijing, one-seventh of the city is without electricity each day. ${ }^{4}$ Power shortage forces the industries in Guangzhou, in Guangdong Province, to operate only three days a week. The extensive use of coal for energy also causes problems such as worsening of the greenhouse effect and health complications. ${ }^{1}$

\section{The Solution}

China sees nuclear power as a possible way to help alleviate the problem. Other options include hydropower and oil resources, which the Chinese are also developing. Nuclear power is associated with prestige and world power, making development attractive despite extensive capital costs. With a developed nuclear industry, China will also be able to export its products and technology. There will be less pollution and less need for extensive transportation although there will still be the need for a power distribution system. The FBIS Daily Report: China cited the news agency Xinhua: "with 30 years [sic] development in the nuclear industry, China has shaped a sound system and trained enough engineers and technicians." is from nuclear military-related research, ${ }^{5}$ which led to China's first detonation of an atomic bomb in 1964. China has had research reactors for over 30 years, but the reactors at Qinshan and Daya Bay are the first of their kind for generating electricity; they are not yet in operation. (See Fig. 1 and the Appendix.)

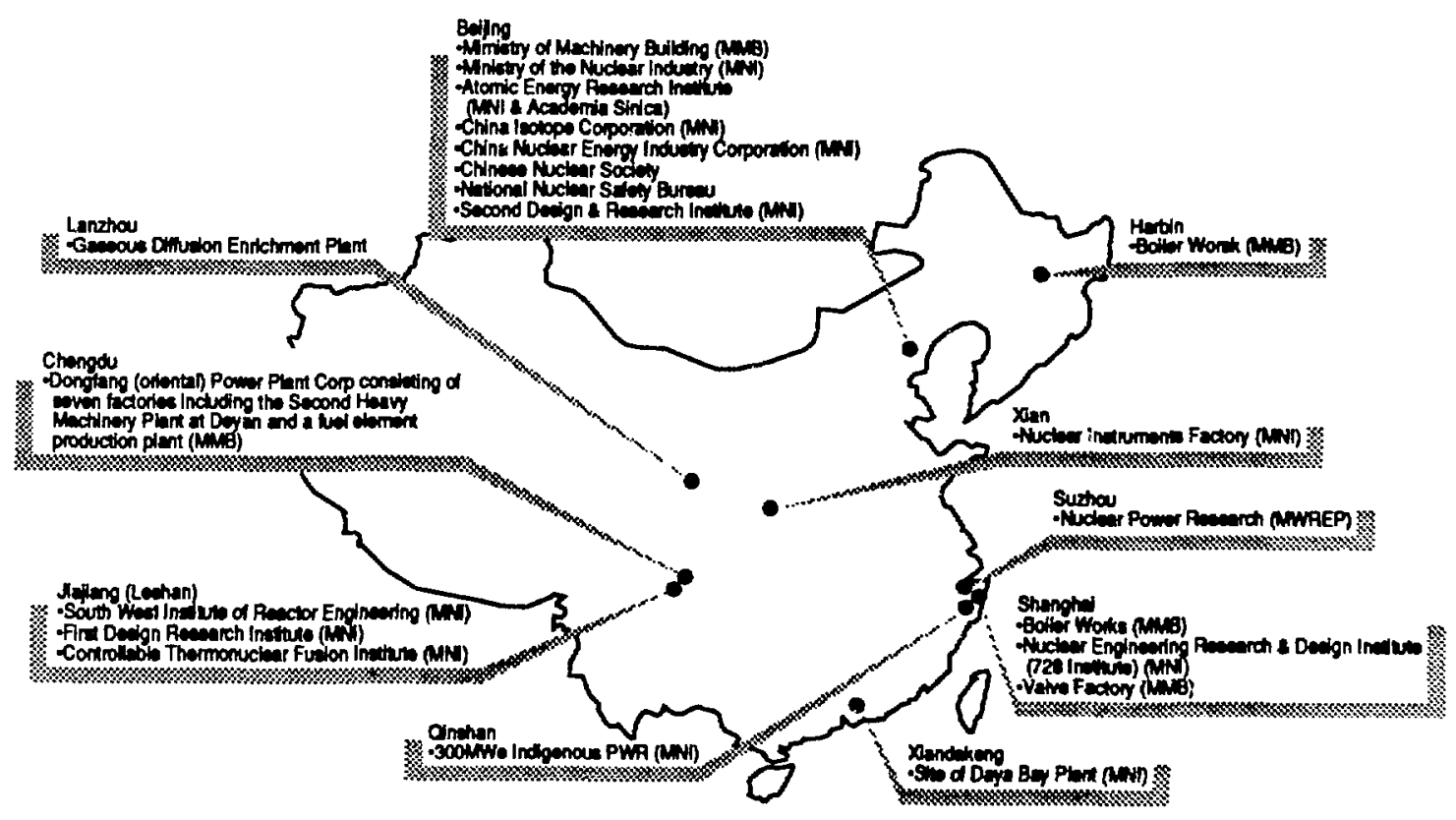

Fig. 1. Nuclear reactor sites in China. [From Nuclear Engineering Intemational 32(398), 40-41 (September 1987)] 


\section{POWER PRODUCTION}

\section{Future Plants}

Chinese nuclear experts believe that they will be able to produce $4500 \mathrm{MW}$ of power by the year 2000. The China National Nuclear Corporation (CNNC) has a goal of $6000 \mathrm{MW}$ by the end of the century and an additional $6000 \mathrm{MW}$ under construction. ${ }^{6}$ Besides the Qinshan and Daya Bay plants, power will come from an addition to Qinshan and other nuclear power plants in energy-short areas of the country. The original figure for the year 2000 was lowered from 10 gigawatts after more detailed research.' The second stage of the Qinshan reactor is two 600-MW pressurized water reactors (PWRs) that were originally scheduled to be finished by $1995 .^{8}$ The actual completion date will probably be much later as basic design is not scheduled for completion until the fall of $1991 .^{9}$

Another plant, planned for the northeastern Liaoning province, will be built and installed by the Soviets; the design will be very different from that of the Chernobyl plant that was involved in the 1986 accident. ${ }^{10}$ Construction contracts were being discussed in early 1991 for a 1000-MWe (megawatt electric) plant. ${ }^{11}$ The Chinese would also like to install and use lowtemperature nuclear heat reactors if a demand can be created. ${ }^{12}$

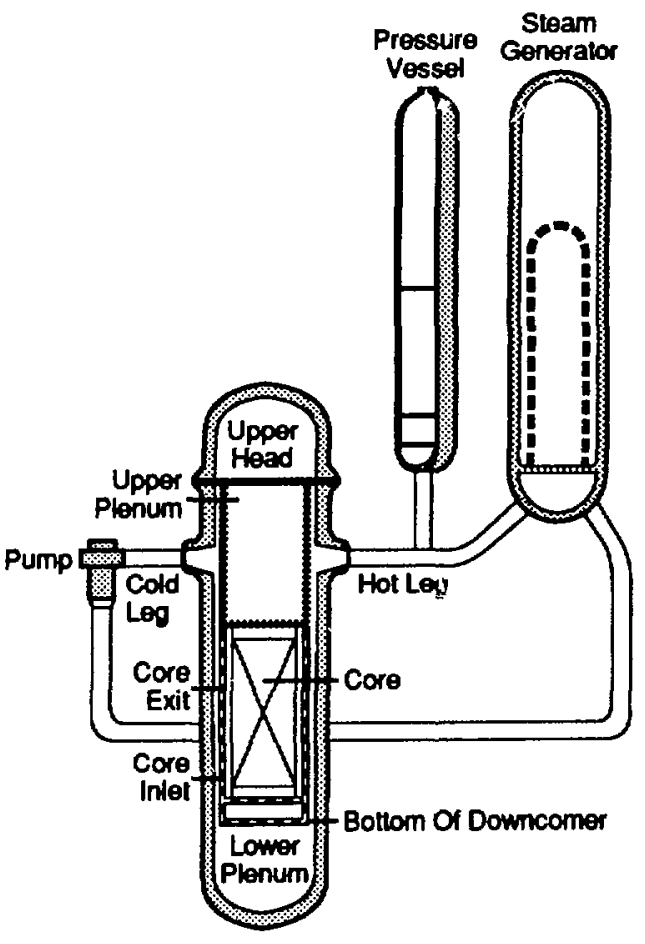

Fig. 2. Basic layout of a PWR
The China Nuclear Energy Industry Corporation (CNEIC) is adjusting to peacetime production of nuclear products. Last year $40 \%$ of its total output value was civilian products, and by the end of the century that figure should reach $80 \% .{ }^{13}$

China is building three power reactors, one at Qinshan, in Zheijang Province, and the other two at Daya Bay in Guangdong Province north of Hong Kong. All the units are PWRs. The basic components of a PWR include the reactor vessel, the steam generator, and the pressurizer (Fig. 2).

A PWR has some basic safety features. Its control rods are held in place by electromagnets, so that if there is an emergency, power can be cut and gravity will pull the control rods down into the core to stop the reaction. Another feature is a containment structure that prevents release of radioactive gases that might be lost if a pipe in the primary system breaks. A supply of coolant also protects the reactor core. ${ }^{14}$ 


\section{The Qinshan Power Plant}

The Qinshan reactor (Fig. 3) is a 300-MWe PW'R, the first reactor designed and built entirely by the Chinese. The project, begun in 1983, was originally scheduled to go into operation in late 1989 but is now scheduled to go on line in 1991, over a year behind schedule.

The plant was built with a state investment of 1.2 billion yuan ( $\$ 255$ million), with $80 \%$ of materials coming from domestic sources. ${ }^{15}$ The pressure vessel, steam evaporator, and voltage regulator all came from the industrial center around Shanghai. ${ }^{16}$ Only a few key components came from foreign sources, such as Japan, France, West Germany, and the United States. $^{15}$

The Qinshan plant is a two-loop PWR with 16 auxiliary systems and a thermal output of $966 \mathrm{MW} .{ }^{17}$ The reactor has three protective shields: a zirconium cover on the nuclear fuel, the reactor vessel, and the reactor building itself. ${ }^{18}$ The fuel assembly is made up of 204 fuel rods $10 \mathrm{~mm}$ in diameter joined in a 15 -by-15 square array. There are eight spacer grids at

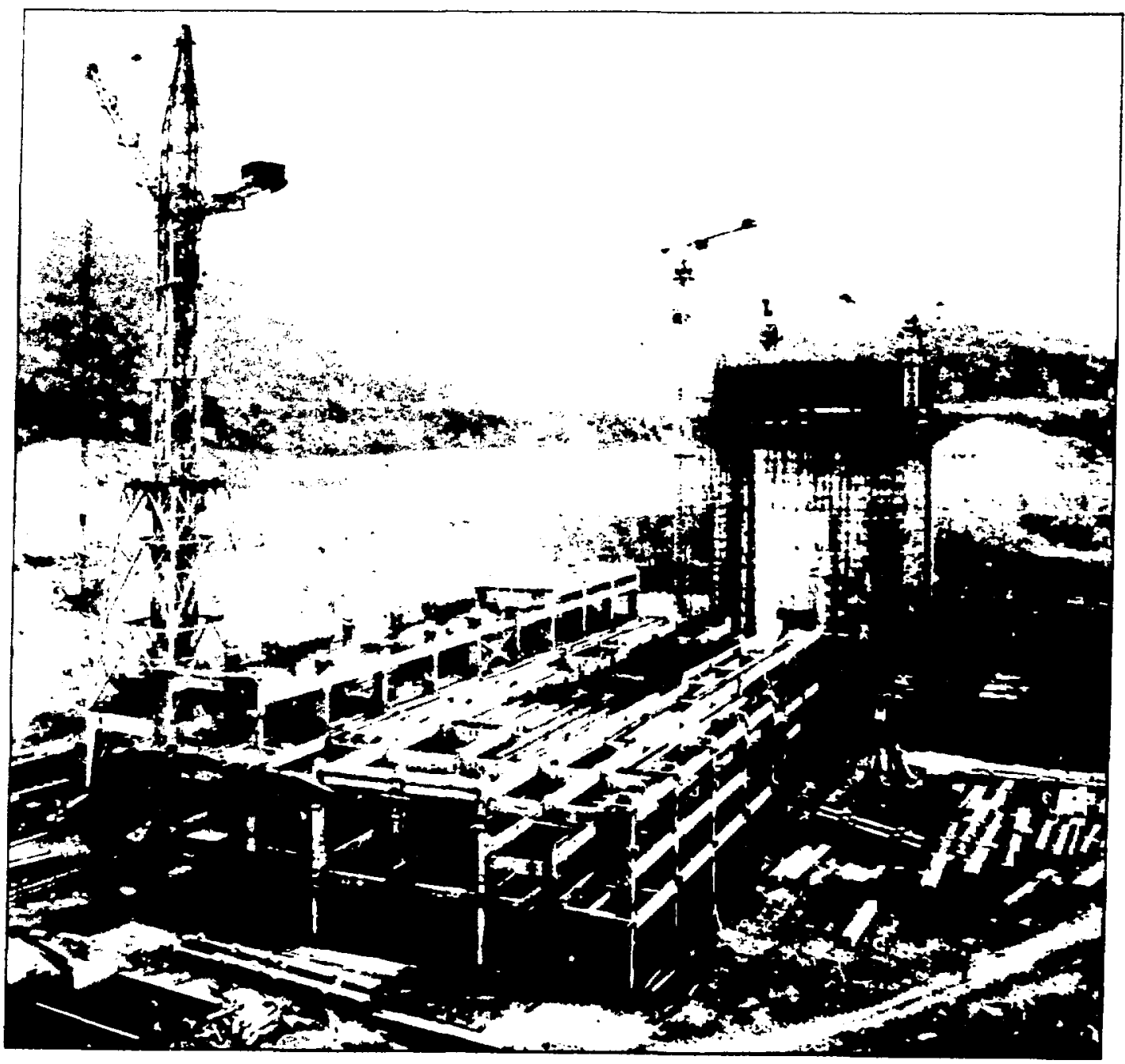

Fig. 3. Qinshan in September 1987. [From Nuclear Engineering Intemational 32(400), 12 (November 1987)] 
intervals along the length. It has an active length of $2.9 \mathrm{~m}$ and an overall length of $3.5 \mathrm{~m} .{ }^{19}$ To control the reaction, Qinshan uses boric acid solution and 37 control rod assemblies with a latchtype magnetic jack-drive mechanism. ${ }^{20}$

The Qinshan plant suffered some difficult structural defects, which have now been corrected. The welding on the safety shell for the reactor building had some defects but "advanced technology was applied to rectify the quality of work which was later proved to be up to standard" according the head of the Chinese National Nuclear Safety Administration. Problems were also discovered in the foundation of the steam turbine building. An inspection found holes in the concrete foundation, so the building was pulled down and rebuilt.' Most of the major equipment, including the moisture separator reheater, the fuel equipment, and the pressure shell and steam generator, all passed state-level inspections in 1989 and $1990 .^{21}$

When the Qinshan plant is completed, it will be connected to the East China power grid, supplying 2 million MWh of electricity a year to the area. ${ }^{22}$ A source noted that one reason for the small size of the Qinshan unit is that it is "suitable for China's power grids, the capacities of which are still not large enough."23 In other words, Qinshan will be able to provide energy, but its distribution may be another problem.

In mid-1990, the opening of Qinshan Nuclear Power Plant was postponed for safety considerations. China noted no serious problems, only the desire to do more testing. Studies would also be done to ensure the plant's resistance to earthquakes. ${ }^{24}$ In July 1990, a hydrostatic pressing test was conducted. Reactor coolant system and auxiliary system tests were to be conducted after the hydrostatic test. ${ }^{25}$

In September 1990, an agreement between Japan Atomic Industrial Forum and CNNC was reached to expedite cooperation in the areas of power reactor design, nuclear medicine, environmental protection, and radioactive waste management. The agreement also provides for Japanese power engineers to help with the startup of Qinshan. Fuel loading is planned for February 1991, with power production to begin 6 months later. 9

\section{The Daya Bay Power Plant}

The Daya Bay nuclear power plant will have two PWRs, each with a capacity of $900 \mathrm{MWe}$. The project is owned by the Guangdong Nuclear Power Joint Venture Co., Ltd (GNPJVC), which was established after several years of negotiations between the Guangdong Electric Power Industrial Company and the China Light \& Power Company (CLP) of Hong Kong. Guangdong Electric Power Industrial Company owns 75\%; CLP owns 25\% (Fig. 4). A contract was signed between the two companies in February 1985, and construction began shortly thereafter.

Electricite de France (EDF) is a project consultant ${ }^{26}$ responsible for the balance of plant, ${ }^{27}$ among other duties. (Balance of plant includes everything except the primary circuit of the reactor, that is, the reactor itself, the primary coolant system, and the associated instrumentation.) Framatome of France supplies the nuclear portion, such as the reactor vessel, steam generator, and pressurizer; and General Electric Company of Britain supplies the generators. ${ }^{28}$. The civil works are a joint venture led by Campenon-Bernard of France and Maeda of Japan. Also included in the joint venture is Hua Xing Company, which is attached to the Chinese Ministry of Nuclear Power, and the Second Branch of the China State Construction 


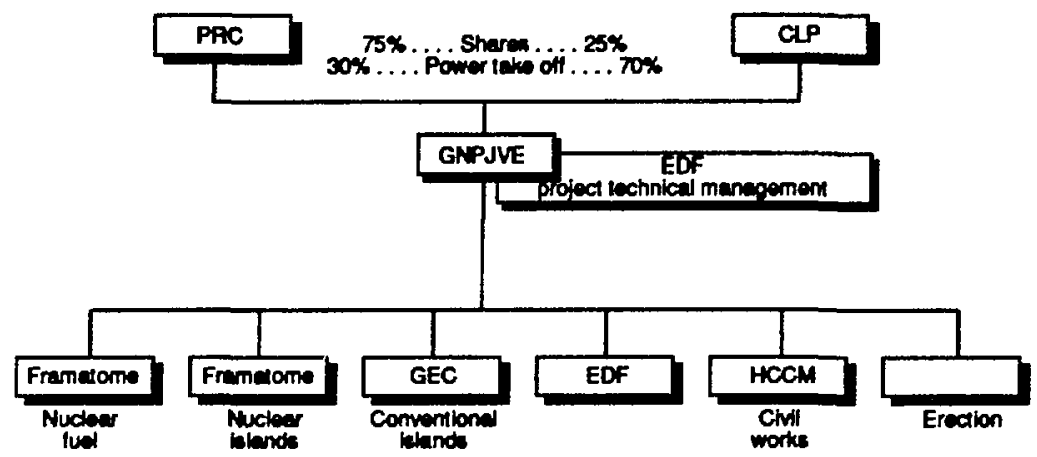

Fig. 4. Onganization of Daya Bay Project. [From Nuclear Engineering Intemational 32(398), 27 (September 1987)]

Engineering Corporation. ${ }^{27}$ GNPJVC divided the construction of the plant among several companies to minimize competition and to ensure that GNPJVC controls the project. ${ }^{27}$

The Daya Bay nuclear power plant is modeled after a French plant, Gravelines 5 and 6, but has a new steam generator design, advanced fuel assemblies, and improved reactor coolant pumps (Fig. 5). ${ }^{27}$ Each unit has a thermal power of $2905 \mathrm{MW}$ and a net electrical output of $900 \mathrm{MW}$. Each uses 157 advanced fuel assemblies. Each assembly comprises a 17-by-17 square grid consisting of fuel rods, guide-thimbles, grids, and top and bottom nozzles.

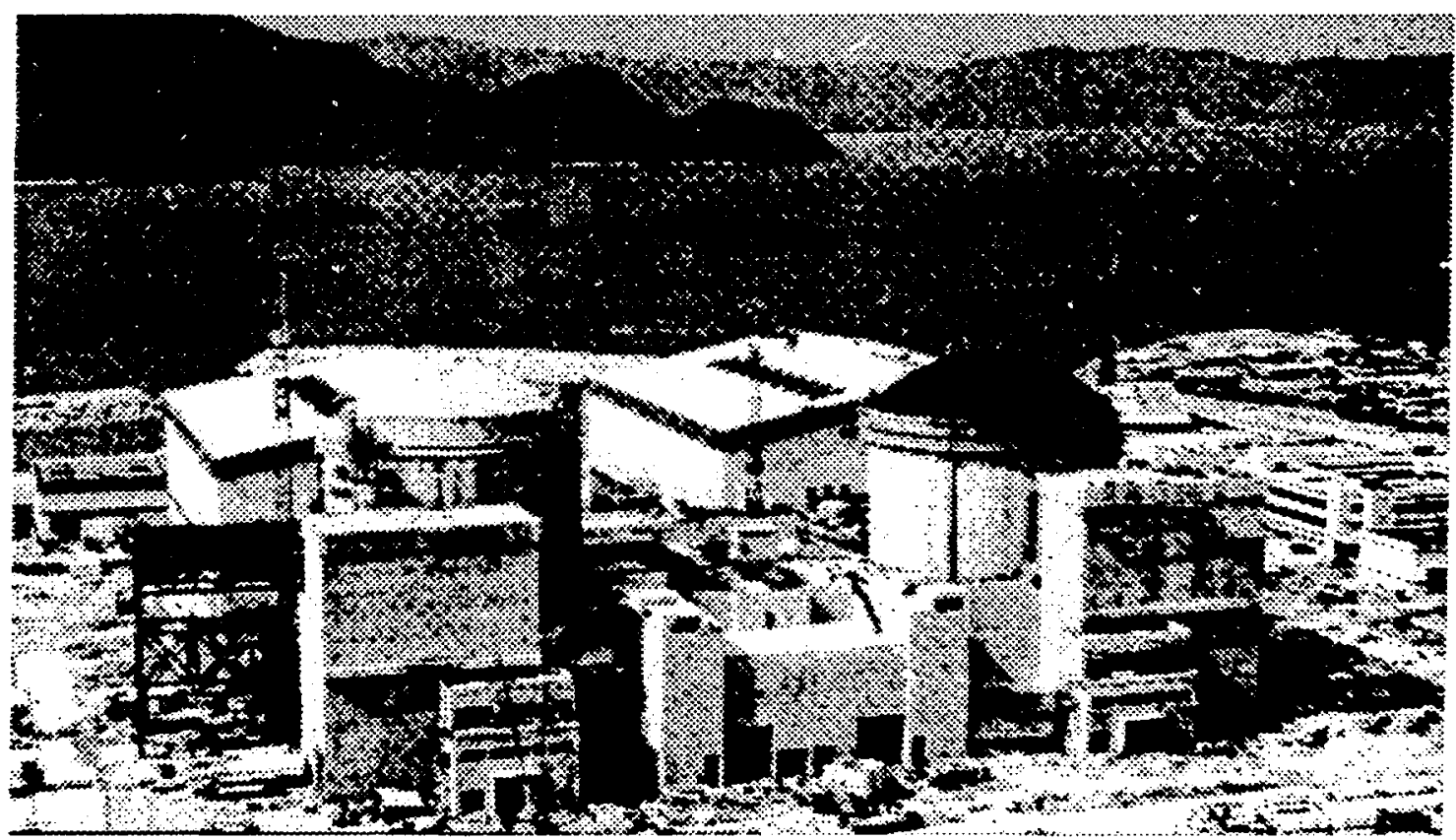

Fig. 5. Daya Bay Nuclear Power Plant. [From Nuclear Engineering Intemational 35(435), 25 (Oaober 1990)] 
The Daya Bay plant also uses mode G-type control rods to increase plant flexibility. - In mode $G$ there are two types of control rods. A gray group is made of a less absorbing material to "minimize perturbations of the core power distribution during rod insertion" [Ref. 27, p. 28]. The other group is made of regular absorbing material, allowing the plant to move from $50 \%$ of thermal power output to $100 \%$ more easily and quickly. ${ }^{27}$ The planned completion of Unit 1 is October 1992, and planned completion of Unit 2 is July $1993,{ }^{28}$ but the actual completion date for the whole plant may be closer to $1994 .^{29}$

The total capital cost of the Daya Bay facility is uncertain. An International Atomic Energy Agency (IAEA) publication, Nuclear Power Performance and Safety Conference Proceedings, ${ }^{28}$ in September 1987 estimated the cost at $\$ 3.7$ billior., but an article in the September 1987 Nuclear Engineering International ${ }^{27}$ estimated the cost at $\$ 2.5$ billion. The GNPJVC is covering about $10 \%$ of the equity; France and England are lending the rest. Hong Kong is also committed to purchasing $70 \%$ of the plant's output. A greater portion of the power must go to Hong Kong instead of mainland China because the GNPJVC needs hard currency to repay its foreign loans.

The Daya Bay reactor has also had its share of construction-related problems. About 300 of the $\mathbf{5 7 6}$ reinforcement bars were omitted from the base of the reactor. Apparently, a technician misinterpreted EDF drawings. At the recommendation of EDF, the missing bars were added, along with additional bars to the second layer of the base. ${ }^{30}$ According to Jiang Shengiie, head of the National Nuclear Safety Administration (NNSA), the work brought the structure up to NNSA standards. ${ }^{31}$

When the Daya Bay plant is ready to go on line, there should be little problem with distribution; the transmission systems of CLP and Guangdong General Power Company are connected. One of the greatest benefits from the new power plant will be the ability to operate factories on the grid at full capacity. Employees will no longer have shortened work weeks caused by lack of energy. The longer work week will give them a full salary, and a better paid work force can only help the economy.

The GNPJVC issued a progress report in October 1990. The plant is on schedule, with Unit 1 slated to begin commercial operation in October of 1992 and Unit 2 to follow 8 months later. The equipment manufacture and civil works are 100\% complete for Unit 1 and about $80 \%$ complete for Unit 2. The water purification plant for the reactors is finished and ready to be used for flushing and testing. ${ }^{32}$

\section{SAFETY}

\section{General}

According to the People's Republic of China Year Book 1987, "China will stick to the policy of safety and quality first as it builds its nuclear power plants. ${ }^{.33}$ All three reactors under construction are PWRs, currently the most widely produced reactor in the world, and they all have three covers to guard against the leakage of radioactive material. The same book lists steps that the Chinese are following to ensure nuclear safety, including maintaining a high degree of quality, stringent safety laws, quality personnel, and other general standards. 
China is also trying to standardize its nuclear safety policy. The National Nuclear Safety Administration has formulated rules on how to implement safety supervision in nuclear power plants. Reference manuals are being put together from the IAEA material. ${ }^{34}$ At the same time China is constantly sending people to international meetings to keep up with the latest safety technology.

A training center at Qinghua University in Beijing can simulate a reactor control room. ${ }^{35}$ The simulator was imported from the United States by the State Nuclear Safety Bureau and given to the university. Based on a PWR, the simulator was originally built for CP\&L Co.'s Shearon Harris Unit 1 reactor in New Hill, NC. ${ }^{36}$

\section{Qinshan}

In March 1989, the IAEA was invited to inspect the Qinshan power station. After a thorough 3-week inspection, the IAEA declared that the plant met all standards. ${ }^{37}$

\section{Daya Bay}

The government requires training of all nuclear power plant operators. After studying nuclear theory in China, the staff that will run the Daya Bay plant will go to France for handson training using a PWR similar to the one being installed in Guangdong Province. ${ }^{38}$

A simulator has also been installed for training nuclear power plant operators at Daya Bay. Imported from France, it is based on a simplified version of the two $900-\mathrm{MW}$ reactors currently' being installed. Its primary use is for initial training, but it can also be used to simulate normal and emergency conditions. ${ }^{39}$

Despite all of this training, the LAEA was not impressed. After a 3-week inspection in December 1990, the IAEA team felt that work procedures needed stricter enforcement, recruitment of qualified operators needed to be faster, and the plant needed an off-site emergency plan. The IAEA also expressed concern about working conditions (three accidental deaths had already occurred) and said that workers sometimes "skipped procedures. ${ }^{40}$

There has been some concern about a fault line discovered by the State Seismological Bureau of China that is only $7.5 \mathrm{~km}$ from the Daya Bay site. The discovery was made public by an organization in Hong Kong in January 1989.41 On November 26, 1989, an earthquake was recorded by the Royal Observatory in Hong Kong. The epicenter was about 60 miles from the Daya Bay Nuclear Power Plant and about 100 miles from Hong Kong. The quake registered 4.2 on an open-ended Richter scale, but there were no reported casualties or damage. ${ }^{42}$

Some people are also worried about the proximity of Hong Kong to Daya Bay (Fig. 6). However, a report released by the United Kingdom Atomic Energy Authority said that Hong Kong does not need an emergency evacuation plan because Daya Bay is far enough away. ${ }^{43}$ In any case, emergency evacuation of Hong Kong is next to impossible because of population density and lack of another place for people to go. 


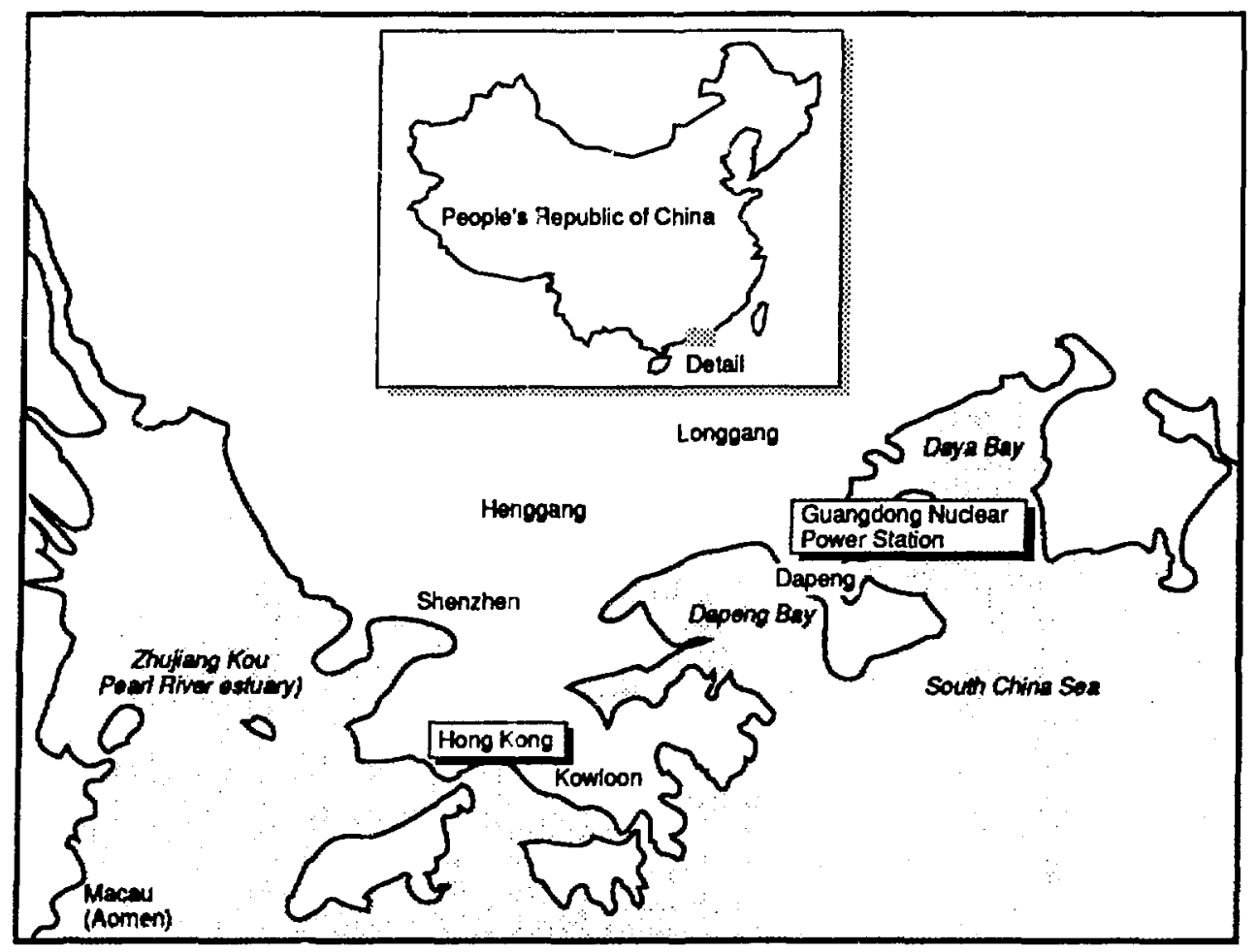

Fig. 6. Location of Daya Bay relative to Hong Kong. [Adapted from Nuclear Engineering Intemational 32(398), 32 (September 1987)]

\section{NUCLFAR FUEL}

China announced that it has discovered 200 uranium deposits, mostly in its southern regions. A survey of one-third of the China's land area noted that China's uranium resources can meet short-term energy needs but will not be able to sustain a lasting program. ${ }^{43}$ The announcement was made at an IAEA meeting, probably held in May 1990. Most of China's uranium resources are in Shanxi and Xinjiang provinces in the north and the Yunnan, Guangxi, Guangdong, and Hunan provirices of the southeast (Fig. 7). In Hengyang, south of Changsha in Hunan Province, there is a mill devoted to the export of uranium. It has a reported ore capacity of 725000 tons per year, yielding 1000 tons of uranium per year. It is estimated that China has 100000 tons of uranium in "economically exploitable reserves" and at least 800000 total tons."

CNEIC supplies nuclear fuel to both Daya Bay and Qinshan. It will supply low-level enriched uranium for the production of fuel assemblies. CNEIC has been supplying fuel to foreign nations such as France, Belgium, Finland, and the Federal Republic of Germany for several years. ${ }^{45}$ 


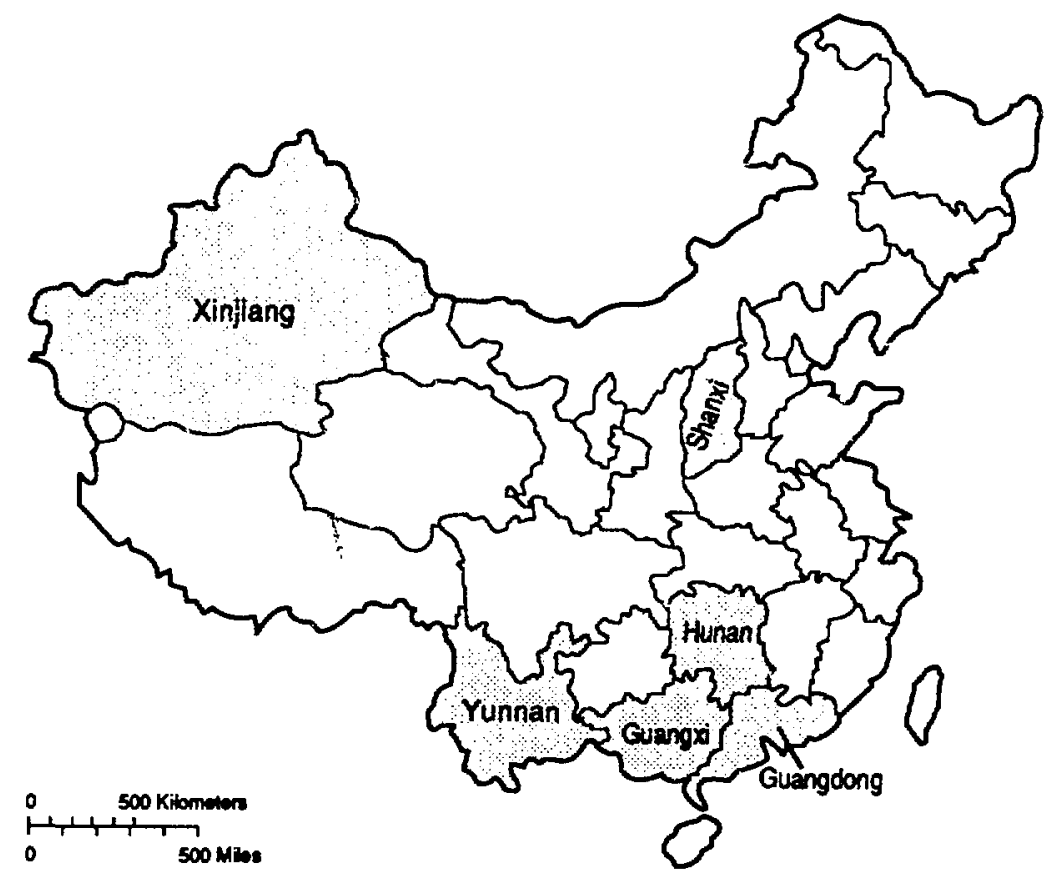

Fig. 7. Provinces containing major uranium deposits.

\section{NUCLEAR WASTE}

\section{Disposal}

The first permanent nuclear waste dumps were proposed in early 1989 . They were to be in the east and northwest. The one in the east would probably receive waste from both the Qinshan and Daya Bay plants. The dump in the northwest would receive waste from the nuclear weapons testing area. Currently, all nuclear waste is stored in temporary dumps. ${ }^{46}$

\section{Reprocessing Plans}

China is in the early stages of waste management and needs to conduct further research. $^{46}$ Chinese nuclear specialists agree that China should reprocess its spent fuel. After spending 3 to 5 years at reactor site pools, the fuel will be transported to the reprocessing plant in northwest China, probably located somewhere in the Gobi desert. There are several reasons that China decided on that plan.

- Uranium and plutonium cannot be recovered unless the fuel is reprocessed.

- Mining of uranium is expensive.

- After removal of uranium and plutonium, waste disposal is safer. ${ }^{47}$ 
The waste will probably then be encased in cement or undergo shallow burial. A processing plant based on the Purex system (separation of plutonium and uranium from fission products in used fuel reprocessing) will be able to handle $100 \mathrm{~kg}$ per day of spent fuel from PWRs. ${ }^{48}$

\section{RELATED ACTIVITY}

\section{Nuclear Component Production}

A production base for nuclear power components is to be built in the southwest province of Sichuan. It is needed to ensure the ability to build ennugh nuclear power plants by the year 2000. There are also plans to upgrade the Yibin fuel components factory in Sichuan so it can produce components for $600-\mathrm{MW}$ and $900-\mathrm{MW}$ nuclear power plants instead of just components for $300-\mathrm{MW}$ plants. ${ }^{49}$

\section{Exports}

Xinhua reported that in 1988 China exported $\$ 38$ million worth of nuclear products, including natural uranium, other metals, and minireactors. Products were exported to 15 different countries, including the United States, Japan, and Australia. ${ }^{50}$ In 1989, the CNEIC exported $\$ 60$ million worth of nuclear fuel to western nations. This type of economic support is important to China, and the economic growth of China depends on products that are competitive with the world market. At this point China is probably the leader in nuclear exports to the third world.

In early 1990, China announced that it would sell a 300-MWe PWR to Pakistan. This deal, added to other exports, would have helped China become a major exporter of nuclear power. However, it apparently fell through after Pakistan talked with France. Pakistan probably found the French offer more appealing considering its proven technology.

\section{CONCLUSIONS}

China needs more energy sources and will continue to pursue the nuclear option. A viable nuclear industry will benefit the economy greatly. Not only will factories be more productive, but more jobs will be provided in the nuclear industry as it grows to meet demand in both domestic and international markets. However, having nuclear power plants means that China must be prepared to handle the accompanying responsibilities of operating safety and proper disposal of radioactive waste. The Chinese have said from the beginning that safety and quality will come first, and they must follow through because a serious accident in such a populated country would be disastrous.

\section{ACKNOWLEDGMENT}

The author thanks Robert L. Bingham of the Department of Energy for his support. 


\section{REFERENCES}

1. "Head of Nuclear Society on Nuclear Development," JPRS-TND-88-017, 21 September 1988. Interview with Jiang Shengiie.

2. He Jiachen and Qian Jihui, "High Temperature Gas Cooled Reactors in China," in Design Requirements, Operation and Maintenance of Gas-cooled Reactors, International Working Group on Gas-Cooled Reactors (LAEA, Vienna, June 1989), pp. 35-38.

3. "Further on Allocations," FBIS Daily Report: China, 236, 33 (1989).

4. R.E. Malenfant, Los Alamos National Laboratory, slide show of trips to China in 1987 and 1988, July 19, 1989.

5. "Nuclear Energy Called Only Answer to Shortage," FBIS Daily Report: China, 147, 27 (1989).

6. "Plans for More Nuclear Power Plants Announced," FBIS Daily Report: China, 100, 32 (1990).

7. "Number of Plants Reevaluated," FBIS Daily Report: China, 199, 45 (1988).

8. "Official Cited on Plans for Nuclear Power," FBIS Daity Report: China, 34, 34 (1989).

9. $\quad$ "Japan to Aid Qinshan Startup," Nuclear Engineering Intemational 35 (437), 4 (December 1990).

10. "Purchase of Soviet Nuclear Power Plant Planned," FBIS Daily Report: China, 50, 3 (1990).

11. "Another Nuclear Plant Planned for Zhejiang," Xinhua News Agency, British Broadcast Corporation Summary of World Broadcasts.

12. Peng Shilu, "Present Status and Prospects of Nuclear Power Development in China," Transactions of the American Nuclear Society, Proceedings of the Sixth Pacific Basin Nuclear Conference, September 7-11, 1987, Beijing, PRC, Vol. 56, Supplement 1, pp. 2-5.

13. "Nuclear Industry Expands Civilian Production," FBIS Daily Report: China, 138, 22 (1990).

14. Jacques Leclercq, The Nuclear Age (Sodel, Paris, 1986), pp. 100-114.

15. "Final Test For Nuclear Power Plant," China Daily: Shanghai Focus, June 11, 1990, p. 3.

16. "Shanghai Source for Qinshan Plant Equipment," FBIS Daily Report: China, 135, 25 (1990).

17. Yu O. "Design and Construction of the Qinshan Nuclear Power Plant," in Transactions of the American Nuclear Society, Vol. 49, Supplement 1, pp. 294-303. 
18. Ma Jianming, "New Atomic Age: History Visits Qinshan Again As China's First Nuclear Power Plant Rises Beside It," Energy Developments 10, $32-34$ (December 1986)

19. Dai Shouhui, Zhou Yinian, and Tong Dingcang, "Present Status and Development of PWR Fuel in China," Transactions of the American Nuclear Society, Proceedings of the Sixth Pacific Basin Nuclear Conference, September 7-11, 1987, Beijing, PRC, Vol. 56 (56'), Supplement 2, pp. 463-473.

20. "China Develops Its Own PWR," Nuclear Engineering International 30(376), 20-21 (November 1985).

21. "Nuclear Power Component Installed in Qinshan," FBIS Daily Report: China, 33s, 36 (1990).

22. "Testing Time for Nuclear Power Plant," China Daily: Business Weekly, July 30, 1990, p. 4.

23. Yu Ouyang, "Present Status and Future Development of Qinshan Nuclear Power Project," Transactions of the American Nuclear Society, Proceedings of the Sixth Pacific Basin Nuclear Conference, September 7-11, 1987, Beijing, PRC, Vol 56 (56'), Supplement 1, pp. 88-90.

24. "State Delays Use of First Nuclear Plant," FBIS Daily Report: China, 142, 16 (1990).

25. "Commissioning 'Ready to Begin' at Qinshan," Nuclear Engineering International 35(433), 3 (August 1990).

26. "Power Industry Accord Signed with France," FBIS Daily Reports: China, 119, 5 (1990).

27. B. Fert, "China Imports French and British Technology for a Twin Unit PWR Station," Nuclear Engineering International 32(398), 26-38 (September 1987).

28. Lu Guohua and Wang Chengziao, "Economic Results of a Joint Venture to Construct a Nuclear Power Station," in Proceedings, Nuclear Power Performance and Safety, Vienna, 28 September-2 October 1987, Vol. 2, pp. 241-248.

29. "Power Station Equipment To Be Imported," SWB (Summary of World Broadcasts) Part 3: The Far East Weekly Economic Report, W0062, A4 (1989).

30. "Work on Guangdong Restarts as QA Problems Are Addressed," Nuclear Engineering Intemational 33 (402), 14-15 (January 1988).

31. "Nuclear Mistakes Hinder China's Progress." JPRS-TND-88-017, 21 September 1988, p. 9.

32. "Construction at Guangdong Moves into Final Phase," Nuclear Engineering Intemational 35(435), 25 (October 1990).

33. People's Republic of China Year Book 1987 (Xinhua Publishing House, Beijing, 1987), p. 435. 
34. "Standardizing Supervision of Nuclear Safety," SWB (Summary of World Broadcasts) Part 3: The Far East Weekly Economic Report, W0042, A4, (1988).

35. "Nuclear Dry Run," China Pictorial 7, 13 (1988).

36. "General Conditions of Beijing Nuclear Power Plant Simulator," He Dong Li Gong Cheng, 10(3), 92-93 (1989).

37. "Official on Qinshan Nuclear Plant," FBIS Daily Report: China 9s, 34 (1990).

38. "Training in France To Begin," FBIS Daily Report: China 54, 45 (1989).

39. "Basic Principle Simulator is Working in Guangdong Dayawan Nuclear Power Station," He Dong Li Gong Cheng 10(1), 10 (1989).

40. Ann Scott Tyson, "China's Nuclear Plan--On the Line," The Christian Science Monitor, December 28, 1990, p. 6.

41. "Spokesman of Hong Kong Branch of Xinhua Answers Journalists' Questions Concerning Discovery of Fault Line at Daya Bay," FBIS Daily Report: China 19, 49 (1989).

42. "Moderate Quake Recorded in South China," United Press International, November 26, 1989, Sunday, BC cycle.

43. "Uranium Deposit," China Daily, May 28, 1990, p. 3.

44. A. D. Owen and Penelope N. Neal, "China's Potential As An Energy Exporter," Energy Policy 15(5), 485-500 (October 1989).

45. "Guangdong Nuclear Plant to Get Enriched Uranium," FBIS Daily Report: China 175, 72 (1988).

46. "Permanent Nuclear Waste Dumps Slated," FBIS Daily Report: China 34, 35 (1989).

47. Jiang Yunqing, Yang Fengting, and Wang Shisheng, "Preparing For Reprocessing of Spent Fuel From Nuclear Power Plants in China," in Proceedings, Nuclear Power Performance and Safety, Vienna, 28 September- 2 October 1987, Vol. 5 (Nuclear Fuel Cycle), pp. 639-641.

48. Jaderna Energie 34(6), 239, (1988).

49. "State to Build Nuclear Component Production Base," FBIS Daily Report: China 227, 22 (1989).

50. "China's Nuclear Product Exports Increasing," Japan Economic Newswire, February 1, 1989. 


\section{APPENDIX \\ CHINESE NUCLEAR RESEARCH REACTORS}

TABLE A-I

NUCLEAR RESEARCH REACTORS IN CHINA'

\begin{tabular}{|c|c|c|c|c|}
\hline Reactor & $\begin{array}{l}\text { Criticality } \\
\text { Date }\end{array}$ & $\begin{array}{l}\text { Power } \\
\text { (MWt) }\end{array}$ & Type & Location \\
\hline HWRR-II & 1958 & 15 & Heavy Water & $\begin{array}{l}\text { Institute of Nuclear } \\
\text { Engineering, Beijing }\end{array}$ \\
\hline SPR IAE & 1964 & 3.3 & Pool & Same \\
\hline Tsinghua & 1964 & 2.8 & Pool, 2 cores & Tsinghua Univ., Beijing \\
\hline Zero power & 1976 & 0.0 & Fast Critical & $\begin{array}{l}\text { Southwest Fast Reactor } \\
\text { and Design Center, } \\
\text { Chengdu }\end{array}$ \\
\hline SPRR-300 & 1979 & 3.0 & Pool & $\begin{array}{c}\text { Institute of Nuclear } \\
\text { Physics and Chemistry, } \\
\text { Sichuan }\end{array}$ \\
\hline HFETR & 1979 & 125 & Tank & $\begin{array}{c}\text { South-west Centre for } \\
\text { Reactor Engineering } \\
\text { Research and Design, } \\
\text { Chengdu }\end{array}$ \\
\hline HFETR critical & 1979 & 0.0 & Critical Assembly & $\begin{array}{l}\text { Southwest Institute for } \\
\text { Reactor Engineering, } \\
\text { Chengdu }\end{array}$ \\
\hline MNSR & 1984 & $27(\mathrm{~kW})$ & Tank in Pool & $\begin{array}{l}\text { Institute of Nuclear } \\
\text { Engineering, Beijing }\end{array}$ \\
\hline
\end{tabular}

'Source: Directory of Nuclear Research Reactors, IAEA, Vienna, Austria, 1989, pp. 76-91. 